\title{
HUBUNGAN KELIMPAHAN IKAN CHAETODONTIDAE DENGAN KONDISI TERUMBU KARANG DI PERAIRAN DESA BUTON, KABUPATEN MOROWALI
}

\author{
Relationship between Chaetodontidae Fish with Coral Reef Conditions \\ in Buton Village Waters, Morowali Regrency
}

\author{
Lisna $^{1}$, La Ode Muh. Yasir Haya ${ }^{2}$, Ratna Diyah Palupi ${ }^{3}$ \\ ${ }^{1}$ Mahasiswa Ilmu Kelautan \\ Fakultas Perikanan dan Ilmu Kelautan Universitas Halu Oleo \\ Jl. HEA Mokodompit Kampus Bumi Tridharma Anduonohu Kendari 93232 \\ ${ }^{2}$ Surel: lmyasir.haya@gmail.com \\ 33urel: pratna97@yahoo.com
}

\begin{abstract}
Abstrak
Terumbu karang merupakan ekosistem laut dangkal yang sangat produktif dan menjadi habitat berbagai biota laut termasuk Ikan famili Chaetodontidae. Ikan famili Chaetodontidae adalah salah satu ikan indikator pada ekosistem terumbu karang. Penelitian ini bertujuan untuk mengetahui kondisi terumbu karang, kelimpahan ikan Chaetodontidae, serta untuk mengetahui hubungan kelimpahan ikan Chaetodontidae dengan kondisi terumbu karang. Pengambilan data dilakukan pada bulan Maret 2019 berlokasi di Perairan Desa Buton, Provinsi Sulawesi Tengah. Data tutupan karang diperoleh dengan menggunakan metode Line Intercept Transect (LIT), sedangkan data ikan Chaetodontidae diperoleh dengan menggunakan metode Underwater Visual Sensus, dengan luas transek $150 \mathrm{~m}^{2}$, dilakukan pada 2 titik stasiun di zona reef flat dan reef slope, dengan dua kali pengulangan. Hasil study menunjukkan bahwa rata-rata kondisi karang di lokasi penelitian termasuk dalam kategori sedang $(44,63 \%)$. Kondisi tutupan karang di stasiun-I dikategorikan baik yaitu zona reef flat $(73,03 \%)$ dan reef slope $(74,08 \%)$, sedangkan stasiun-II masuk dalam kategori buruk yaitu $15,68 \%$ pada reef flat dan 15,75\% pada reef slope. Ikan Chaetodontidae yang ditemukan berjumlah 68 individu, yang terdiri atas dua genus dan delapan spesies, antara lain; Chaetodon kleinii, C. lineolatus, C. lunula, C. lunulatus, C. octofasciatus, C. vagabundus, Heniochus chrysostomus, H. varius. Berdasarkan stasiun penelitian, kelimpahan ikan Chaetodontidae tertinggi ditemukan di stasiun-I. Sedangkan berdasarkan zonasi terumbu karang, kelimpahan ikan Chaetodontidae tertinggi ditemukan di zona reef slope. Hubungan kelimpahan ikan Chaetodontidae dengan persentase tutupan karang hidup pada zona reef flat dan reef slope adalah memiliki hubungan yang kuat dengan nilai $\mathrm{r}=0,991$ (reef flat) dan $\mathrm{r}=$ 0,967 (reef slope). Sebaliknya, berdasarkan stasiun penelitian keduanya memiliki hubungan yang lemah dengan nilai $\mathrm{r}=$ 0,586 (Stasiun-I) dan $\mathrm{r}=0,189$ (Stasiun-II).
\end{abstract}

Kata Kunci: Desa Buton, Ikan Chaetodontidae, Kelimpahan, Terumbu Karang.

\begin{abstract}
A coral reef is a very productive shallow marine ecosystem and serves as a habitat for a variety of marine life, including the Chaetodontidae family fish. The Chaetodontidae family fish is one of the indicator fish in coral reef ecosystems. This study aims to determine the condition of coral reefs, abundance of Chaetodontidae fish, and to determine the relationship of the abundance of Chaetodontidae fish to coral reef conditions. Data was collected in March 2019, located in the waters of Buton Village, Central Sulawesi Province. Coral cover data were obtained using the Line Intercept Transect (LIT) method, while Chaetodontidae fish data were obtained using the Underwater Visual Census method, with a transect area of $150 \mathrm{~m}^{2}$, performed at two station points in the reef flat and reef slope zones, with two repetitions. The results of the study showed that the average condition of corals in the study area was included in the moderate category (44.63\%). The condition of coral cover at Station-I was categorized as good, namely reef flat zone $(73.03 \%)$ and reef slope $(74.08 \%)$, while station-II was in a bad category at $15.68 \%$ in the reef flat and $15.75 \%$ in the reef slope. The Chaetodontidae fish found were 68 individuals, consisting of two genera and eight species, including; Chaetodon kleinii, C. lineolatus, C. lunula, C. lunulatus, C. octofasciatus, C.vagabundus, Heniochus chrysostomus, H. varius. Based on the research station, the highest abundance of Chaetodontidae fish was found at Station-I. While based on the coral reef zone, the highest abundance of Chaetodontidae fish is found in the reef slope zone. The relationship of the abundance of Chaetodontidae fish with the percentage of live coral cover on the reef flat and reef slope is having a strong relationship with $r=0.991$ (reef flat) and $\mathrm{r}=0.967$ (reef slope). In contrast, based on the research station, both have a weak relationship with the value of $\mathrm{r}=0.586$ (Station-I) and $\mathrm{r}=0.189$ (Station-II).
\end{abstract}

Keywords: Buton Village, Chaetodontidae Fish, Abundance, Coral Reef.

\section{Pendahuluan}

Terumbu karang merupakan ekosistem yang produktif dan sangat beranekaragam jenis serta bentuknya. Keanekaragaman jenis dan produktivitasnya hanya dapat disetarakan dengan ekosistem hutan hujan tropis di daratan (Purnama, 2013). Ekosistem terumbu 
karang sebagai salah satu ekosistem laut penting memiliki fungsi ekologi, yaitu sebagai tempat tinggal, tempat mencari makan (feeding ground), tempat memijah (spawning ground), daerah asuhan (nursery ground), dan tempat berlindung bagi hewan laut lainnya (Dhananjaya $d k k .$, 2017).

Ikan famili Chaetodontidae adalah salah satu jenis ikan karang penghuni terumbu karang dan merupakan spesies ikan indikator karena ikan tersebut memiliki keterkaitan yang erat dengan terumbu karang yaitu sebagai tempat tinggal sekaligus sebagai sumber makanan (Laikun $d k k$, 2014). Ikan ini memanfaatkan polip karang sebagai makanannya, sehingga diduga eksploitasi ekosistem terumbu karang dapat memberi pengaruh terhadap kelimpahan dan komposisi jenis ikan Chaetodontidae (Nurjirana dan Burhanuddin, 2017).

Beberapa penelitian yang pernah dilakukan sebelumnya mengenai kelimpahan ikan Chaetodontidae diantaranya, kelimpahan ikan Chaetodontidae di Perairan Pulau Sambangan memiliki hubungan yang kuat dengan persentase tutupan karang (Suryanti dkk., 2011). Kelimpahan ikan famili Chaetodontidae di Perairan Pulau Ketawai memiliki hubungan yang positif dengan persentase tutupan karang hidup. Hubungan positif tersebut menggambarkan bahwa semakin banyak terumbu karang hidup yang ditemukan, maka semakin banyak ikan famili Chaetodontidae yang ditemukan (Hidayat $d k k ., 2018$ ).
Perairan Desa Buton merupakan salah satu perairan yang terletak di Kecamatan Bungku Selatan, Kabupaten Morowali yang memiliki gugusan terumbu karang dan jenis ikan karang yang beragam. Berdasarkan hasil survey pendahuluan yang telah dilakukan, kondisi fisik terumbu karang yang ada di perairan tersebut bervariasi, mulai dari yang rusak, sedang, hingga baik. Kondisi karang yang rusak diduga akibat adanya aktivitas kapal, pemutihan karang (bleaching), dan sebagian akibat adanya aktivitas pengeboman yang pernah dilakukan. Hal tersebut diduga menyebabkan terjadinya degradasi tutupan karang di beberapa tempat sehingga sebaran ikan Chaetodontidae di perairan tersebut mulai berkurang. Tujuan dari penelitian ini yaitu untuk mengetahui kondisi terumbu karang, mengetahui kelimpahan ikan Chaetodontidae, serta mengetahui hubungan kelimpahan ikan Chaetodontidae dengan kondisi terumbu karang di Perairan Desa Buton, Kabupaten Morowali.

\section{Bahan dan Metode}

Penelitian ini telah berlangsung selama delapan bulan mulai Desember 2018-Juli 2019 meliputi tahapan persiapan, pengambilan data lapangan, pengolahan data dan sampai pembuatan laporan penelitian. Pengambilan data dilaksanakan pada bulan Maret 2019 dan bertempat di Perairan Desa Buton, Kecamatan Bungku Selatan, Kabupaten Morowali, Sulawesi Tengah (Gambar 1).

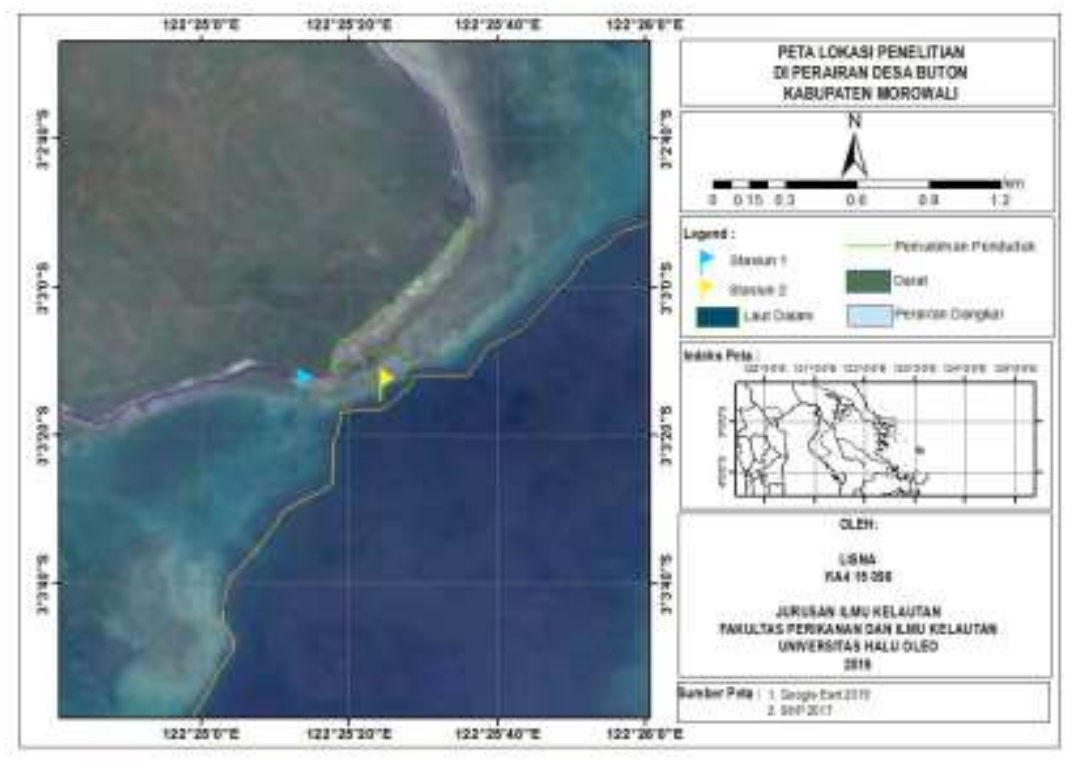

Gambar 1. Peta Lokasi Penelitian (Sumber: Google Earth.com, 2019) 
Tabel 1. Alat dan bahan beserta kegunaannya

\begin{tabular}{|c|c|c|c|c|c|}
\hline \multirow{2}{*}{\multicolumn{6}{|c|}{ Alat dan Bahan }} \\
\hline & & & & & \\
\hline 1 & Thermometer Air Raksa & & ${ }^{\circ} \mathrm{C}$ & Mengukur suhu perairan & 2 \\
\hline 2 & Layangan Arus & & $\mathrm{m} / \mathrm{s}$ & Mengukur kecepatan arus & 1 \\
\hline 3 & Stopwatch & & $\mathrm{s}$ & Menghitung waktu & 1 \\
\hline 4 & Secchi Disk & & $\%$ & Mengukur kecerahan & 1 \\
\hline 5 & $\mathrm{pH}$ Indikator & & - & Mengukur $\mathrm{pH}$ & 1 \\
\hline 6 & Hand refractometer & & $\%$ & Mengukur salinitas & 1 \\
\hline 7 & GPS Garmin 76CX & & - & Mengambil titik koordinat & 1 \\
\hline 8 & Roll Meter & & $\mathrm{m}$ & Memasang transek & 6 \\
\hline 9 & Kamera Underwater & & unit & Mendokumentasikan kegiatan & 4 \\
\hline 10 & SCUBA & & set & Alat bantu untuk menyelam & 3 \\
\hline \multicolumn{6}{|c|}{ B. Bahan } \\
\hline 11 & $\begin{array}{l}\text { Buku Identifikasi Ikan } \\
\text { (Giyanto } d k k ., 2014 \text { ) }\end{array}$ & Karang & - & Mengidentifikasi ikan karang & 1 \\
\hline 12 & $\begin{array}{l}\text { Buku Identifikasi } \\
\text { (Suharsono, 2008) }\end{array}$ & Karang & - & $\begin{array}{l}\text { Mengidentifikasi bentuk pertumbuhan } \\
\text { karang }\end{array}$ & 1 \\
\hline 13 & Terumbu Karang & & - & Objek pengamatan & - \\
\hline 14 & Ikan Chaetodontidae & & - & Objek pengamatan & - \\
\hline
\end{tabular}

Langkah awal sebelum melakukan penelitian yaitu dengan melakukan survey pendahuluan terlebih dahulu. Survey ini bertujuan untuk melihat kondisi awal lokasi penelitian dan informasi yang relevan dengan penelitian. Hasil dari survey ini yang dijadikan sebagai dasar untuk menentukan titik pengambilan data (stasiun penelitian).

Penentuan stasiun penelitian ditentukan dengan menggunakan metode "purposive sampling" yaitu penentuan stasiun berdasarkan keberadaan karang dan ikan Chaetodontidae. Pada tahap ini, setiap stasiun dilakukan pengambilan titik koordinat menggunakan GPS Garmin 76CX. Lokasi pengambilan data penelitian terdiri dari dua stasiun, yaitu;

Stasiun I : Terletak pada titik koordinat $03^{\circ} 3^{\prime} 37,31^{\prime \prime}$ LS dan $122^{\circ} 25^{\prime} 10,71^{\prime \prime}$ BT, stasiun ini jauh dari pemukiman masyarakat dan aktivitas yang berhubungan dengan masyarakat. Stasiun II: Terletak pada titik koordinat 03'3'37,77' LS dan $122^{\circ} 25^{\prime} 21,63^{\prime \prime}$ BT, stasiun ini berdekatan dengan pemukiman masyarakat, berdekatan dengan dermaga dan merupakan tempat bekas pengeboman.

Metode yang digunakan untuk pengambilan data tutupan karang yaitu metode Line Intercept Transect (LIT) (English et al., 1994). Metode ini digunakan untuk menentukan kondisi terumbu karang berdasarkan bentuk pertumbuhan karang. Pengambilan data tutupan karang dilakukan dengan cara menarik garis transek (roll meter) sepanjang $30 \mathrm{~m}$ sejajar garis pantai pada daerah reef flat dan reef slope dengan dua kali ulangan. Pengambilan data dilakukan dengan cara mencatat semua bentuk pertumbuhan karang (lifeform) dan komponen abiotik yang berada dibawah garis transek dengan bantuan alat scuba diving. Hasil pengamatannya dicatat hingga ketelitian sampai centimeter $(\mathrm{cm})$.

Transek yang digunakan untuk mendata ikan Chaetodontidae sama dengan yang digunakan untuk mendata terumbu karang. Pengamatan ikan Chaetodontidae pada stasiun penelitian dilakukan dengan menggunakan metode sensus visual bawah air (Underwater Visual Sensus) (English et al., 1994). Cara kerja metode ini yaitu dengan menarik garis transek sepanjang 30 $\mathrm{m}$ sejajar garis pantai pada daerah reef flat dan reef slope dengan lebar area pengamatan sepanjang $5 \mathrm{~m}$ yaitu $2,5 \mathrm{~m}$ disebelah kanan transek dan 2,5 m disebelah kiri transek (luas $150 \mathrm{~m}^{2}$ ) dengan dua kali ulangan dan interval $10 \mathrm{~m}$. Pengambilan data ikan Chaetodontidae dilakukan pada siang hari dikarenakan ikan jenis ini aktif pada siang hari (Diurnal).

Pengamatan dan pengukuran nilai-nilai parameter fisika kimia oseanografi perairan dilakukan langsung di setiap stasiun penelitian. Parameter fisika kimia oseanografi yang diukur meliputi suhu, salinitas, $\mathrm{pH}$, kecepatan arus, dan kecerahan. Pengukuran parameter ini dilakukan setelah 
pengambilan data ikan dan karang sebagai parameter penunjang dalam melakukan penelitian.

Kondisi terumbu karang dapat dilihat berdasarkan persentase tutupan karang hidup. Persentase tutupan karang hidup dihitung menurut persamaan English et al, (1994):

$L=\frac{\mathrm{Li}}{\mathrm{N}} \times 100$

Dimana:

$\mathrm{L}=$ Persentase tutupan karang $(\%)$

$\mathrm{Li}=$ Panjang lifeform (intercept koloni) jenis kategori ke-i

$\mathrm{N}=$ Panjang transek

Penentuan kondisi terumbu karang

berdasarkan Keputusan Menteri Negara

Lingkungan Hidup No. 4 Tahun 2001

Tentang Kriteria Baku Kerusakan Terumbu Karang.

Tabel 2. Kriteria Baku Kerusakan Terumbu

Karang berdasarkan Keputusan Menteri Negara Lingkungan Hidup No.4 Tahun 2001.

\begin{tabular}{cc}
\hline Kategori & $\begin{array}{c}\text { \% Tutupan Karang } \\
\text { Hidup }\end{array}$ \\
\hline Buruk & $0-24,9$ \\
Sedang & $25-49,9$ \\
Baik & $50-74,9$ \\
Baik Sekali & $75-100$ \\
\hline
\end{tabular}

Kelimpahan ikan Chaetodontidae adalah jumlah individu ikan yang ditemukan per satuan luas. Analisis Kelimpahan ikan karang menurut Odum (1971) dihitung dengan rumus:

$X=\frac{x i}{n}$

Dimana:

$\mathrm{X}=$ Kelimpahan ikan karang (ind. $/ \mathrm{m}^{2}$ )

$\mathrm{xi}=$ Jumlah individu ikan jenis ke-i yang diperoleh pada tiap stasiun (ind.)

$\mathrm{n}=$ Luas daerah pengamatan $\left(\mathrm{m}^{2}\right)$

Analisis yang digunakan untuk melihat hubungan kondisi terumbu karang hidup dengan kelimpahan ikan Chaetodontidae adalah Analisis Regresi Linier Sederhana dengan menggunakan program excel dengan rumus:

$$
y=a+b x
$$

Dimana:

$\mathrm{y}=$ Variabel terikat (ikan Chaetodontidae)

$\mathrm{x}=$ Variabel bebas (tutupan karang hidup)

$\mathrm{a}=$ Intersept (perpotongan garis regresi dengan sumbu-y)

$\mathrm{b}=$ Koefisien regresi

\section{Hasil dan Pembahasan}

Rata-rata kondisi karang di lokasi penelitian masuk dalam kategori sedang (44,63\%). Berdasarkan Gambar 2 dan 3, persentase tutupan karang hidup di stasiun I menunjukkan hasil lebih tinggi dibanding stasiun II, baik pada zona reef flat dan reef slope $(73,03 \%$ dan $74,08 \%)$. Kondisi tutupan karang di stasiun I masuk kategori baik. Hal tersebut dikarenakan letak stasiun yang jauh dari pemukiman masyarakat sehingga aktivitas yang berhubungan langsung dengan masyarakat masih jauh dari tempat tersebut. Selain itu, kondisi beberapa parameter perairan yang masih termasuk normal dan mendukung pertumbuhan karang, sebagai contoh yaitu suhu $\left(32^{\circ} \mathrm{C}\right)$, salinitas $(35 \%)$, kecepatan arus $(0,11 \mathrm{~m} / \mathrm{s})$, dan kecerahan $(100 \%)$.

Hal ini diduga sebagai alasan stasiun ini memiliki kondisi terumbu karang yang lebih baik dibandingkan stasiun II. Menurut Rahman (2007), bahwa perairan yang memiliki lokasi berjauhan dan tidak berhadapan langsung dengan lokasi pemukiman akan memiliki persentase tutupan terumbu karang yang lebih baik dibanding dengan lokasi yang berdekatan dan berhadapan langsung dengan pemukiman penduduk dan juga tergantung dengan substrat dasar. Menurut Supriharyono (2000), bahwa karang dapat hidup pada suhu berkisar $17-36^{\circ} \mathrm{C}$ dan semakin banyak sinar yang diterima oleh terumbu karang maka semakin baik pula tingkat pertumbuhan karang tersebut. Riansyah $d k k$. (2018), menyatakan bahwa kecerahan merupakan salah satu faktor lingkungan yang sangat penting karena sangat bertanggungjawab dalam memberikan cahaya bagi Zooxanthellae sebagai simbion terumbu karang.

Stasiun II memiliki persentase tutupan karang hidup yang lebih rendah dibandingkan stasiun I. Nilai persentase tutupan karang hidup pada stasiun II sebesar 15,68\% (reef flat) dan 15,75\% (reef slope). Kondisi terumbu karang di stasiun II ini masuk dalam kategori buruk. Hal ini diduga disebabkan karena letak stasiun ini yang berdekatan dengan pemukiman masyarakat sehingga aktivitas yang berhubungan langsung dengan masyarakat seperti aktivitas penangkapan ikan yang tidak ramah lingkungan dan aktivitas kapal mempengaruhi pertumbuhan karang dan bahkan 
menyebabkan kerusakan pada karang itu sendiri. Rahman (2007), menyatakan bahwa aktivitas manusia seperti penangkapan ikan, pengambilan terumbu karang batu, pembuangan limbah rumah tangga dapat mengakibatkan kerusakan bagi terumbu karang di suatu daerah.

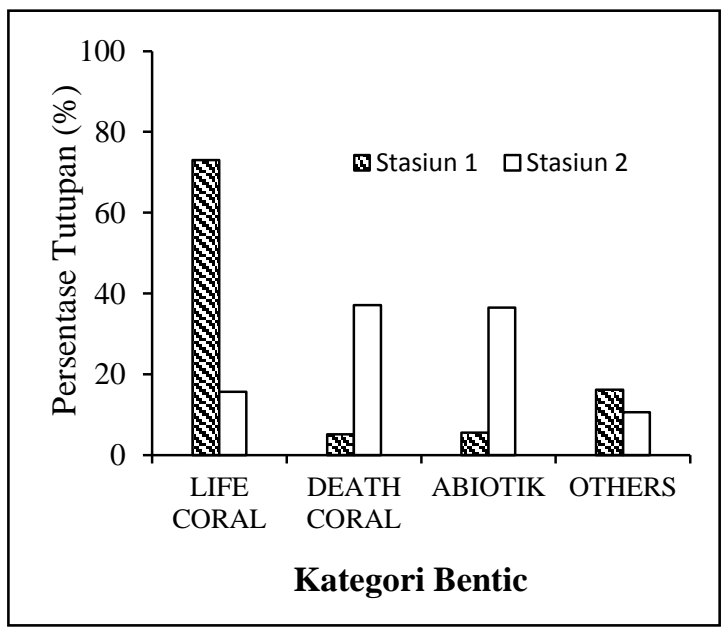

Gambar 2. Grafik Persentase Tutupan Karang pada daerah reefflat

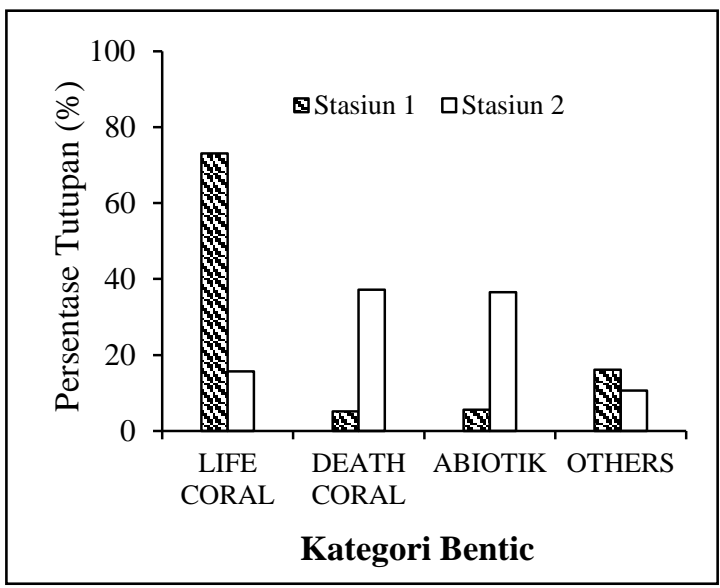

Gambar 3. Grafik Persentase Tutupan Karang pada daerah reef slope

Berdasarkan hasil penelitian, jumlah ikan yang ditemukan pada stasiun penelitian yaitu sebanyak 68 individu yang masuk dalam dua genus dan delapan spesies. Berdasarkan Gambar 4 dan 5 terlihat bahwa, Chaetodon kleinii adalah spesies ikan famili Chaetodontidae yang dominan ditemukan pada daerah reef flat dan reef slope. Banyaknya ikan $C$. kleinii pada lokasi penelitian di Perairan Desa Buton berkaitan juga dengan kebiasaan makan dari spesies ini yang bersifat facultative corallivores dan omnivora. Sifat facultative corallivores pada ikan ini yang menyebabkan ikan ini tidak sensitif terhadap perubahan yang terjadi pada ekosistem terumbu karang. Spesies ikan ini juga lebih menyukai karang bercabang yang ada pada perairan tersebut. Laikun $d k k$. (2014), menyatakan bahwa, Chaetodon kleinii merupakan salah satu spesies dari Chaetodontidae yang sangat umum ditemukan di daerah terumbu karang, bahkan pada daerah-daerah yang telah mengalami kerusakan, karena spesies ini tidak hanya memangsa polip karang lunak, tetapi juga memakan alga dan zooplankton. Nurjirana dan Burhanuddin (2017), menyatakan bahwa jenis ikan Chaetodon kleinii memiliki ketertarikan terhadap karang bercabang, baik sebagai area pemangsaan maupun sebagai tempat perlindungan.

Pada stasiun II (Gambar 4), terdapat 2 jenis ikan Chaetodontidae yang ditemukan di reef flat namun tidak ditemukan di reef slope, yaitu Chaetodon lineolatus dan $C$. lunula dengan kelimpahan individu masing-masing sebesar 0,007 ind. $/ \mathrm{m}^{2}$. Sebaliknya terdapat 1 jenis ikan Chaetodontidae yang ditemukan di reef slope namun tidak ditemukan di reef flat (Gambar 5) yaitu C. vagabundus dengan kelimpahan individu sebesar 0,007 ind. $/ \mathrm{m}^{2}$. Hal tersebut diduga disebabkan oleh keberadaan sumber makanan dari jenis ikan tersebut. Selain itu, meningkatnya persentase tutupan karang mati menyebabkan penurunan yang nyata dalam jumlah spesies ikan maupun individu-individu ikan yang berasosiasi dengan terumbu karang.

Ikan Chaetodontidae jenis $H$. varius adalah spesies ikan Chaetodontidae yang hanya ditemukan pada stasiun I dengan kelimpahan individu 0,020 ind. $/ \mathrm{m}^{2}$ dan 0,013 ind. $/ \mathrm{m}^{2}$ (Gambar 4 dan 5). Hal ini karena kondisi tutupan karang pada stasiun I termasuk dalam kategori baik sehingga sumber makanan untuk ikan jenis ini melimpah, dimana spesies ikan ini makanannya berupa polip karang dan zooplankton. Hal ini sesuai dengan Fishbase (2009), yang menyatakan bahwa umumnya spesies ikan Heniochus memakan polip karang dan hewan invertebarata lainnya.

Hasil analisis kelimpahan ikan Chaetodontidae (Gambar 4 dan 5) pada dua stasiun penelitian, diperoleh kelimpahan ikan Chaetodontidae tertinggi terdapat di stasiun I baik zona reef flat maupun reef slope. Hal ini disebabkan karena pada stasiun I memiliki 
persentase tutupan karang hidup yang tinggi dan termasuk dalam kategori baik sehingga ketersediaan sumber makanan dari ikan Chaetodontidae masih melimpah pada daerah tersebut. Sementara itu, kelimpahan ikan Chaetodontidae terendah terdapat di stasiun II baik zona reef flat maupun reef slope. Hal ini juga disebabkan karena pada stasiun II memiliki persentase tutupan karang hidup rendah dan termasuk dalam kategori buruk. Rendahnya tutupan karang hidup di stasiun II yang menyebabkan kurangnya ketersediaan sumber makanan dari ikan Chaetodontidae utamanya jenis ikan yang memangsa polip karang sebagai makanannnya sehingga diduga menyebabkan kelimpahan ikan Chaetodontidae yang ditemukan rendah. Hal tersebut menunjukkan bahwa semakin tinggi tutupan karang hidup maka semakin tinggi pula kelimpahan ikan Chaetodontidae dan sebaliknya. Hal ini sesuai dengan pernyataan Riansyah $d k k$. (2018), yang menyatakan bahwa kelimpahan ikan Chaetodontidae tertinggi sangat berkaitan erat dengan tingginya tutupan karang.

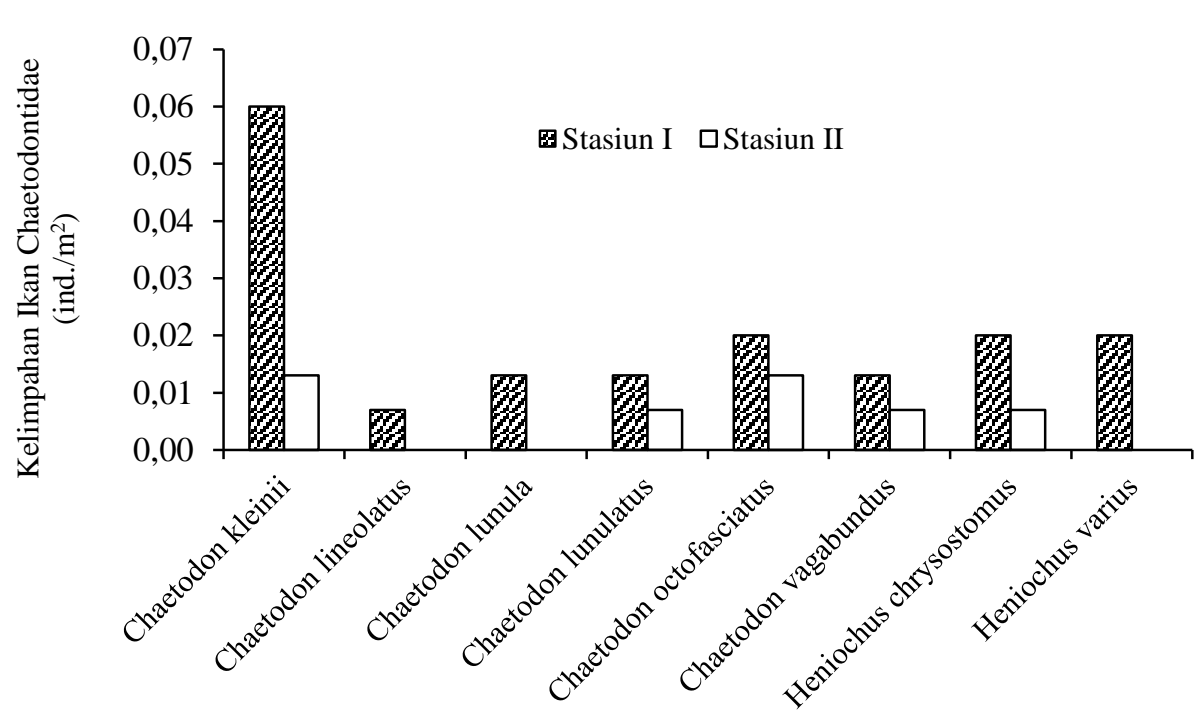

Jenis Ikan Chaetodontidae

Gambar 4. Grafik Kelimpahan Ikan Chaetodontidae pada daerah reefflat

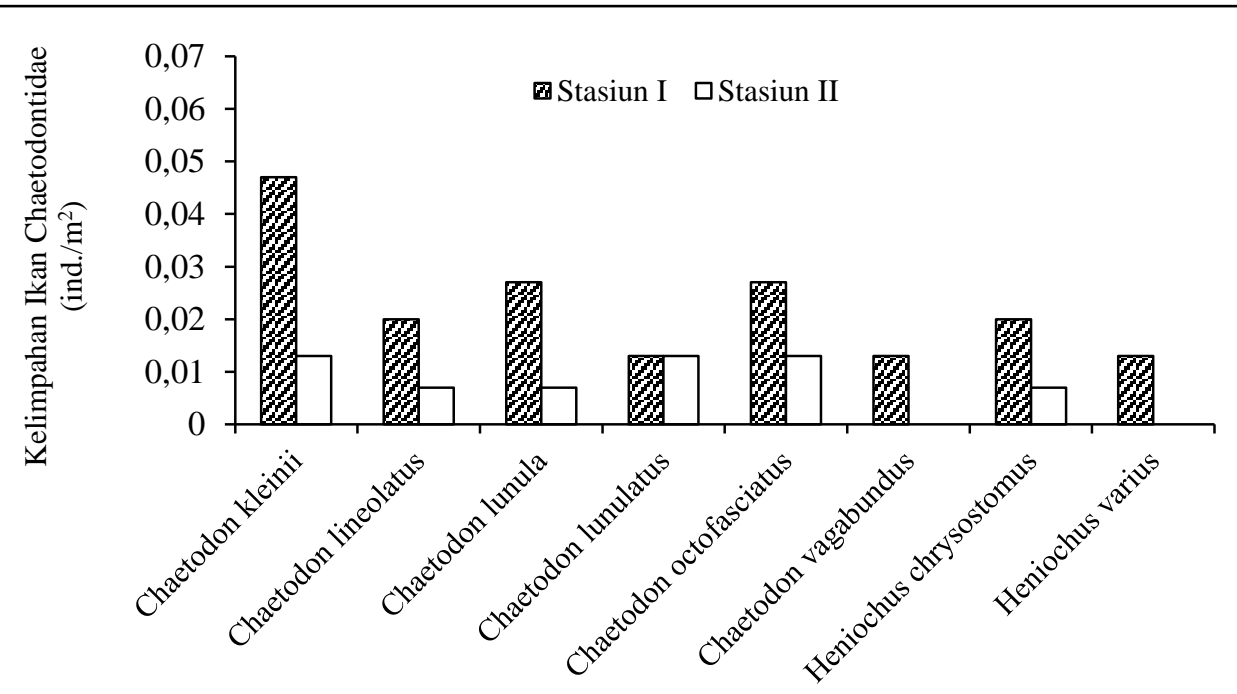

Jenis Ikan Chaetodontidae

Gambar 5. Grafik Kelimpahan Ikan Chaetodontidae pada daerah reef slope 


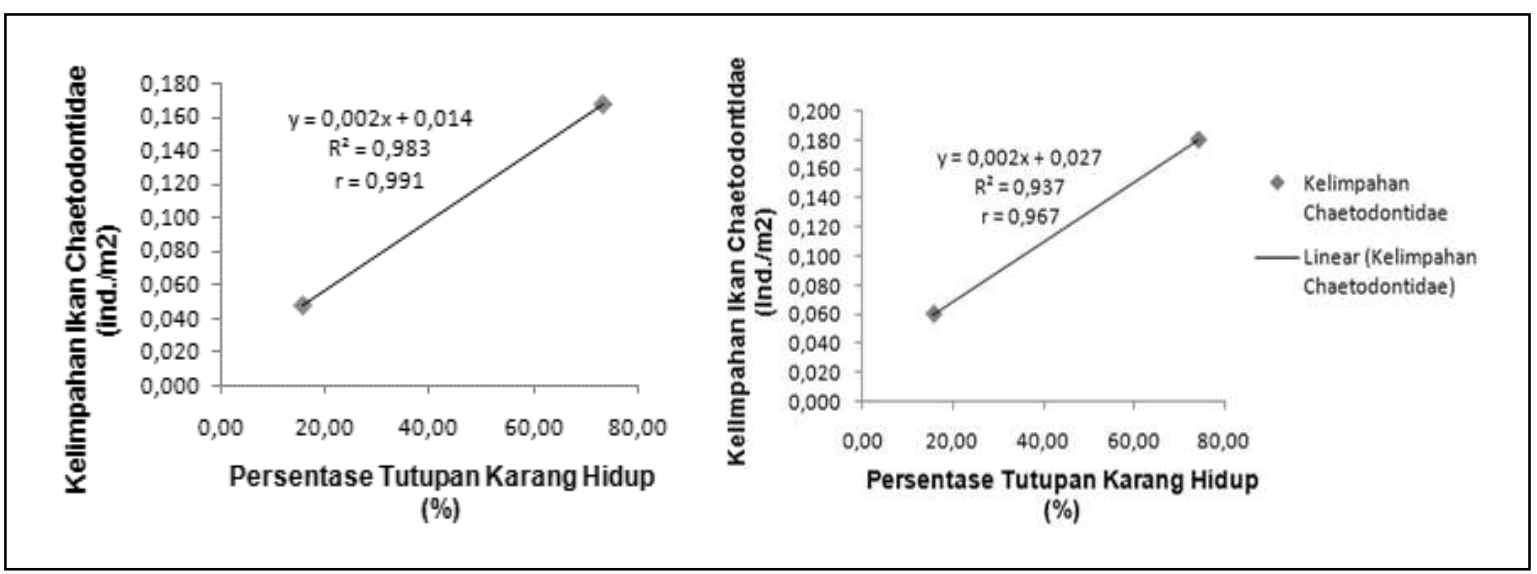

Gambar 6. Hubungan kelimpahan ikan Chaetodontidae dengan persentase tutupan karang hidup di daerah reefflat dan reef slope.

Berdasarkan zonasi terumbu karang, kelimpahan ikan Chaetodontidae tertinggi ditemukan pada daerah reef slope $(0,180$ ind. $\left./ \mathrm{m}^{2}\right)$ sedangkan terendah pada daerah reef flat $\left(0,047 \mathrm{ind} . / \mathrm{m}^{2}\right)$. Hal ini disebabkan kondisi tutupan karang hidup yang berbeda pada setiap lokasi penelitian. Persentase tutupan karang hidup pada zona reef slope lebih tinggi dibandingkan reef flat sehingga kelimpahan ikan Chaetodontidae yang ditemukan pada zona reef slope lebih tinggi dibandingkan reef flat. Kehadiran ikan Chaetodontidae pada perairan juga dipengaruhi oleh faktor fisika kimia oseanografi seperti suhu, salinitas, kecerahan, $\mathrm{pH}$ perairan. Berdasarkan data hasil pengukuran parameter fisika kimia oseanografi diperoleh suhu perairan pada stasiun penelitian berkisar antara $31-32^{\circ} \mathrm{C}$. Souhoka dan Patty (2013), menyatakan bahwa suhu yang berkisar antara $28-32^{\circ} \mathrm{C}$ masih sesuai untuk kehidupan biota laut (ikan dan sebagainya). Hasil pengukuran $\mathrm{pH}$ perairan pada lokasi penelitian sebesar 7-8. Terjadinya perbedaan $\mathrm{pH}$ antara stasiun I (pH 7) dan II ( $\mathrm{pH}$ 8) kemungkinan disebabkan karena pada stasiun II yang masih berdekatan dengan pemukiman masyarakat sehingga aktivitas masyarakat pesisir dapat mempengaruhi $\mathrm{pH}$ di perairan. Keputusan Menteri Negara Lingkungan Hidup No. 51 Tahun 2004 tentang Baku Mutu Air Laut untuk Biota Laut, menunjukkan bahwa biota laut dapat hidup pada $\mathrm{pH}$ berkisar antara 7-8,5.

Hasil analisis regresi linear sederhana yang didapatkan yaitu terdapat hubungan yang positif antara kelimpahan ikan Chaetodontidae terhadap persentase tutupan karang hidup pada daerah reef flat dan reef slope. Hal ini dibuktikan dengan nilai $\mathrm{R}^{2}=0,983$ dan $\mathrm{r}=$ 0,991 pada daerah reef flat dan $\mathrm{R}^{2}=0,937$ dan $\mathrm{r}=0,967$ pada daerah reef slope. Nilai $\mathrm{R}^{2}$ yang diperoleh menunjukkan bahwa persentase tutupan karang hidup memberi kontribusi sebesar $98,30 \%$ di reef flat dan $93,70 \%$ di reef slope terhadap kelimpahan ikan Chaetodontidae. Jika dilihat dari nilai $r$ yang diperoleh, maka dapat disimpulkan bahwa kelimpahan ikan Chaetodontidae memiliki hubungan yang kuat terhadap persentase tutupan karang hidup. Hal ini sesuai dengan pernyataan Maharbhakti (2009), yang menyatakan bahwa persentase tutupan karang hidup memiliki hubungan yang kuat dengan kelimpahan ikan famili Chaetodontidae di Perairan Pulau Abang, yang berarti bahwa persentase penutupan karang keras mempengaruhi kelimpahan ikan famili Chaetodontidae. Sama halnya dengan penelitian yang dilakukan oleh Saputra $d k k$. (2019) di Perairan Lalanu, yang menunjukkan bahwa adanya hubungan yang kuat antara persentase penutupan karang hidup dengan kelimpahan ikan Chaetodontidae.

Hasil analisis regresi linear sederhana yang didapatkan yaitu terdapat hubungan yang negatif antara kelimpahan ikan Chaetodontidae terhadap persentase tutupan karang hidup pada stasiun I dan stasiun II. Hal ini dibuktikan dengan nilai $R^{2}=0,344$ dan $r=0,586$ pada stasiun $\mathrm{I}$ dan $\mathrm{R}^{2}=0,036$ dan $\mathrm{r}=0,189$ pada stasiun II. Nilai $R^{2}$ yang diperoleh menunjukkan bahwa persentase tutupan karang hidup memberi kontribusi sebesar $34,40 \%$ di stasiun I dan 3,60\% di stasiun II terhadap kelimpahan ikan Chaetodontidae. Jika dilihat dari nilai $r$ yang diperoleh maka dapat disimpulkan bahwa terdapat hubungan yang lemah antara kelimpahan ikan Chaetodontidae dengan persentase tutupan karang hidup. 
Dengan demikian, dapat dikatakan bahwa persentase tutupan karang hidup memiliki hubungan yang lemah terhadap kelimpahan ikan Chaetodontidae. Hasil yang didapatkan sama dengan hasil penelitian yang dilakukan oleh Nurjirana dan Burhanuddin (2017) di Perairan Spermonde, Sulawesi Selatan yang menyatakan bahwa kelimpahan ikan Chaetodontidae tidak memiliki hubungan yang kuat terhadap persentase tutupan karang hidup pada stasiun penelitian. Berbeda halnya dengan hasil penelitian yang didapatkan oleh Riansyah $d k k$. (2018) di Pulau Tikus, yang menyatakan bahwa terjadi hubungan positif antara persentase tutupan karang terhadap kelimpahan ikan Chaetodontidae.

Hubungan kelimpahan ikan
Chaetodontidae dengan persentase tutupan karang hidup berdasarkan zonasi terumbu karang memiliki hubungan yang lebih kuat dibanding berdasarkan stasiun penelitian. Hal tersebut diduga dikarenakan berdasarkan zonasi terumbu karang, habitat yang dihubungkan adalah habitat yang sama sehingga peningkatan persentase tutupan karang hidup memberikan konstribusi terhadap peningkatan kelimpahan ikan Chaetodontidae dan menyebabkan hubungan keduanya kuat. Habitat yang dihubungkan adalah habitat yang berbeda sehingga peningkatan persentase tutupan karang hidup tidak memberikan konstribusi terhadap peningkatan kelimpahan ikan Chaetodontidae dan menyebabkan hubungan keduanya lemah.

Spesies ikan Chaetodontidae ada yang bersifat obligate coral feeder (hanya memakan karang sebagai makanannya) dan ada juga yang bersifat facultative coral feeder (hanya memakan sebagian dari polip karang). Kehadiran ikan Chaetodontidae yang bersifat obligate coral feeder mengindikasikan bahwa terumbu karang pada perairan tersebut masih dalam kondisi baik. Berdasarkan hasil studi literatur, ditemukan tiga spesies ikan Chaetodontidae yang bersifat obligate coral feeder (Chaetodon octofasciatus, $\quad C$. lunulatus, Heniochus chrysostomus) dan lima spesies yang bersifat facultative coral feeder (Chaetodon kleinii, C. lineolatus, C. lunula, $C$. vagabundus, Heniochus varius). Hidayat $d k k$. (2018), menyatakan bahwa ikan-ikan dari famili Chaetodontidae merupakan salah satu ikan indikator kesehatan terumbu karang karena ikan Chaetodontidae memanfaatkan karang sebagai makanannya.
Kelimpahan ikan Chaetodontidae di Perairan Desa Buton berbeda pada setiap stasiunnya Keberadaan ikan Chaetodontidae terutama pada spesies Chaetodon kleinii yang ditemukan paling mendominasi pada kedua stasiun penelitian. Hal ini dikarenakan ikan Chaetodon kleinii merupakan spesies ikan Chaetodontidae yang bersifat facultative corallivores (hanya memakan sebagian dari polip karang) dan omnivora. Pada stasiun penelitian, ditemukan pula ikan Chaetodon octofasciatus yang merupakan spesies ikan Chaetodontidae yang bersifat obligate corallivores. Ikan Chaetodon octofasciatus ini banyak ditemukan di daerah yang mempunyai kepadatan Acropora yang tinggi. Hal ini karena genus Acropora dengan bentuk pertumbuhan yang bercabang menyediakan tempat yang aman serta makanan bagi jenis ikan ini. Terumbu karang dari suku Acroporidae mempunyai kandungan protein lebih tinggi (Madduppa, 2006). Ikan Chaetodon octofasciatus dan ikan Chaetodon kleinii, keduanya memiliki ketertarikan terhadap karang bercabang, baik sebagai area pemangsaannya maupun tempat untuk berlindung.

\section{Kesimpulan}

1. Secara umum kondisi karang di lokasi penelitian masuk dalam kategori sedang $(44,63 \%)$. Kondisi tutupan karang hidup di stasiun I masuk dalam kategori baik sedangkan stasiun II masuk dalam kategori buruk.

2. Jenis ikan Chaetodontidae yang ditemukan pada lokasi penelitian sebanyak $\quad 68$ individu yang terdiri dari dua genus dan delapan spesies. Spesies C. kleinii adalah jenis yang paling dominan ditemukan baik berdasarkan stasiun penelitian maupun zonasi terumbu karang. Kelimpahan ikan Chaetodontidae tertinggi berdasarkan stasiun ditemukan di stasiun I sedangkan berdasarkan zonasi terumbu karang kelimpahan ikan Chaetodontidae tertinggi ditemukan di daerah reef slope.

3. Hubungan kelimpahan ikan Chaetodontidae dengan persentase tutupan karang hidup berdasarkan zonasi terumbu karang keduanya memiliki hubungan yang kuat sedangkan berdasarkan stasiun penelitian keduanya memiliki hubungan yang lemah. 


\section{Daftar Pustaka}

Dhananjaya, I.G.N.A., Hendrawan, I.G., Faiqoh, E. 2017. Komposisi Spesies Ikan Karang di Perairan Desa Bunutan, Kecamatan Abang, Kabupaten Karangasem, Bali. Jurnal Of Marine and Aquatic Sciences. Vol. 3(1): 91-98.

English, S., C. Wilkinson and V. Baker. 1994. Survey Manual for Tropical Marine Resources. Australian Institute of Marine Science. Townsvile. 368 pp.

Fishbase. 2009. Database Ikan. www.Fishbase.org. [Dikutip pada 28 Juni 2019].

Giyanto, Manuputty, A.EW., Abrar, M., Siringoringo, R.M., Suharti, S.R., Wibowo, K., Edrus, I.N., Arbi, U.Y., Cappenberg, H.A.W., Sihaloho, H.F., Tuti, Y., Zulfianita, D. 2014. Panduan Monitoring Kesehatan Terumbu Karang. Jakarta: COREMAP CTI LIPI. 71 Hal.

Hidayat, H., Hartoni., Fauziyah. 2018. Hubungan Kondisi Tutupan Terumbu Karang terhadap Kelimpahan Ikan Famili Chaetodontidae di Perairan Pulau Ketawai, Bangka Tengah, Provinsi Bangka Belitung. Maspari Journal. Vol. 10(2):1-17.

Keputusan Menteri Negara Lingkungan Hidup No. 4. 2001. Kriteria Baku Kerusakan Terumbu Karang.

Keputusan Menteri Negara Lingkungan Hidup No. 51. 2004. Baku Mutu Air Laut untuk Biota Laut.

Laikun, J., Rondonuwu, A.B., Rembet, U.N.W.J. 2014. Kondisi Ikan Karang Famili Chaetodontidae di Daerah Perlindungan Laut Desa Bahoi Kecamatan Likupang Barat Kabupaten Minahasa Utara. Jurnal Ilmiah Platax. Vol. 2(3): 92-98.

Madduppa, H. 2006. Kajian Ekobiologi Ikan Kepe-Kepe

(Chaetodon octofasciatus, BLOCH 1787) dalam Mendeteksi Kondisi Ekosistem Terumbu Karang di Pulau Petondan Timur, Kepulauan Seribu, Jakarta. [Tesis]. Insitut Pertanian Bogor. Bogor.

Maharbhakti, HR. 2009. Hubungan Kondisi terumbu Karang dengan Keberadaan Ikan Chaetodontidae di Perairan Pulau Abang, Batam. [Tesis]. Insitut Pertanian Bogor. Bogor.
Nurjirana, Burhanuddin, A.I. 2017. Kelimpahan dan Keanekaragaman Jenis Ikan Famili Chaetodontidae berdasarkan Kondisi Tutupan Karang Hidup di Kepulauan Spermonde Sulawesi Selatan. Spermonde. Vol. 2(3):34-42.

Odum, E. P. 1971. Dasar-dasar Ekologi. Catatan ke-3. Gajah Mada University Press. Yogyakarta.

Purnama, A.A. 2013. Struktur Komunitas Terumbu Karang di Perairan Pulau Pasumpahan. Jurnal Ilmiah Edu Research. Vol. 2(2): 103-110.

Rahman, A., 2007. Kondisi Terumbu Karang Di Perairan Teluk Banten dan Upaya Pengelolaannya. Studi Magister Ilmu Kelautan. Universitas Indonesia. Jakarta. Riansyah, A., Hartono, D., Kusuma, A.B. 2018. Ikan Kepe-Kepe (Chaetodontidae) sebagai Bioindikator Kerusakan Perairan Ekosistem Terumbu Karang Pulau Tikus. A Scientifiv Journal. Vol. 35(2):103-110.

Saputra, M. T., Sadarun, B., Rahmadani, Subhan. 2019. Hubungan antara Kondisi Tutupan Karang Hidup dengan Kelimpahan Ikan Chaetodontidae di Perairan Lalanu, Kecamatan Soropia, Kabupaten Konawe. Jurnal Sapa Laut. Vol. 4(2): 53-60.

Souhoka, J., Patty, S.I. 2013. Pemantauan Kondisi Hidrologi dalam Kaitannya dengan Kondisi Terumbu Karang di Perairan Pulau Talise, Sulawesi Utara

Suharsono. 2008. Jenis-Jenis Karang di Indonesia. Jakarta: LIPI Press. 1-374 Hal.

Supriharyono, 2000. Pelestarian dan Pengelolaan Sumber Daya Alam di Wilayah Pesisir Tropis. Gramedia Pustaka Utama. Jakarta.

Suryanti, Supriharyono, Indrawan, W. 2011. Kondisi Terumbu Karang dengan Indikator Ikan Chaetodontidae di Pulau Sumbangan, Kepulauan Karimun Jawa, Jepara, Jawa Tengah. Vol. 1: 106-119. 